\title{
Analysis of seed vigor and germination of Toona ciliata M. Roem. var. australis ${ }^{1}$
}

\author{
Júlio Rieger Lucchese ${ }^{2 *}$, Marília Lazarotto², Claudimar Sidnei Fior ${ }^{2}$, \\ Larissa Campos de Sá ${ }^{2}$, Carolina Brito Brose ${ }^{2}$
}

\begin{abstract}
Seed analysis tests should be performed under standard conditions for each species, so that the results can be reproducible anywhere. Seeds of the forest species Toona ciliata var. australis have been commercialized in Brazil despite no standard conditions for their analysis have been published. The objective was to determine basic information about temperature and photoperiod for the germination test and the imbibition time and volume of water for electrical conductivity. In the germination test the seeds were incubated at $15,20,25$ and $30^{\circ} \mathrm{C}$ with 0,12 and $16 \mathrm{~h}$ of light. The electrical conductivity was evaluated up to $108 \mathrm{~h}$ after immersion of the seeds in 50 and $100 \mathrm{~mL}$ of deionized water. The conditions of $25^{\circ} \mathrm{C}$ and $16 \mathrm{~h}$ of light provided higher amount of normal seedlings. At $15^{\circ} \mathrm{C}$ all seeds remained hard regardless the photoperiod used, however, it became absent when light was added at higher temperatures. The electrical conductivity test should be performed with a volume of $50 \mathrm{~mL}$ and evaluated after $24 \mathrm{~h}$ of imbibition. It also showed a stronger correlation between normal seedlings, being a promising vigor evaluation test for this species.
\end{abstract}

Index terms: Australian red cedar, viability, conductivity test, seed quality.

\section{Análise do vigor e da germinação de sementes de Toona ciliata $\mathrm{M}$. Roem. var. australis}

\begin{abstract}
RESUMO - As análises de sementes devem ser realizadas em condições padronizadas para cada espécie, para que assim os resultados possam ser reprodutíveis em qualquer lugar. Sementes da espécie florestal Toona ciliata var. australis têm sido comercializadas no Brasil apesar de não haver condições padronizadas publicadas para sua análise. O objetivo foi determinar informações básicas sobre temperatura e fotoperíodo para o teste de germinação e tempo de embebição e volume de água para condutividade elétrica. Para o teste de germinação as sementes foram incubadas a $15,20,25$ e $30^{\circ} \mathrm{C}$ com 0,12 e $16 \mathrm{~h}$ de luz. A condutividade elétrica foi avaliada até $108 \mathrm{~h}$ após imersão das sementes em 50 e $100 \mathrm{~mL}$ de água deionizada. As condições de $25^{\circ} \mathrm{C}$ e $16 \mathrm{~h}$ de luz proporcionaram maior quantidade de plântulas normais. A $15^{\circ} \mathrm{C}$ todas as sementes permaneceram duras independente do fotoperíodo utilizado, entretanto, isso se tornou ausente quando foi adicionado luz em temperaturas maiores. O teste de condutividade elétrica deve ser realizado com volume de $50 \mathrm{~mL}$ e avaliado após $24 \mathrm{~h}$ de embebição. Esse teste também mostrou uma correlação forte entre plântulas normais, sendo considerado então um promissor teste para avaliar o vigor dessa espécie.
\end{abstract}

Termos para indexação: cedro-australiano, viabilidade, condutividade elétrica, qualidade de sementes.

\section{Introduction}

Seed testing contributes to several research areas, which also brings information to both seed producer and buyer. The germination test, considered as an objective and reproducible for the evaluation of seed quality, is one of the most used tests and universally accepted by several entities (Elias et al., 2012).
This test generate economically important information that allow a better understanding of the reproductive strategies of the plant, life history traits and habitat adaptations (Baskin and Baskin, 2014).

Temperature, light and water stress, among other factors, affect the germination process, provoking divergences in the test according to the conditions imposed (Godoi and

${ }^{1}$ Submitted on 04/18/2018. Accepted for publication on 06/19/2018.

${ }^{2}$ Faculdade de Agronomia, Universidade Federal do Rio Grande do Sul, 91540-000 - Porto Alegre, RS, Brasil.

${ }^{*}$ Corresponding author $<$ juliorieger@gmail.com> 
Takaki, 2004; Socolowski and Takaki, 2004; El-Keblawy and Al-Rawai, 2006; Tilki and Dirik, 2007; Yang et al., 2008; Maraghni et al., 2010; Luna et al., 2011; Oliveira et al., 2015). Temperature regulates the seed germination in three ways: determining the capacity and germination rate of nondormant seeds; removing primary or secondary dormancy; and inducing secondary dormancy. High temperatures can induce secondary dormancy (Bewley et al., 2013) and lead to the death of embryos (Oliveira et al., 2015). Seeds at low temperatures are prone to cooling damages and reduced germination (Fenner and Thompson, 2005).

The light requirement for germination can vary according to temperature, and it is often difficult to separate the effects of light from the temperature (Bonner, 2008; Bewley et al., 2013). According to Bonner (2008), light stimulates the germination of many forest species, being absolutely necessary for just a few. An exposure of just a few minutes, seconds or even milliseconds may be sufficient to start the germination process, while others need intermittent illumination for long periods (Bewley et al., 2013).

Seed testing should follow standardized methodologies so that results can be reproducible among seed laboratories. Regulatory institutions such as Association of Official Seed Analysts (AOSA) and International Seed Testing Association (ISTA) provides standard conditions for substrate, temperature, light, evaluation time, overcoming dormancy methods, and criteria for determination of normal and abnormal seedlings (Elias et al., 2012). In Brazil, seed testing is standardized by the Coordenação Geral de Apoio Laboratorial (CGAL) linked to the Ministry of Agriculture, Livestock, and Supply, which publishes the report entitled Regras para Análise de Sementes (Rules for Seed Testing), based on ISTA's rules (Brasil, 2009).

The forest species Toona ciliata M. Roem. var. australis have been widely exploited for having pest-resistant and highquality wood (Bygrave and Bygrave, 2005). Originally from Australia, it had its first plantations in Brazil around the 70's, in which it found favorable edaphoclimatic conditions for its development (Vilela and Stehling, 2015). It has an advantage in relation to the Brazilian cedars due to its smaller production cycle and the absence of attacks by Hypsipyla grandella, and can be used to reduce the overexploitation of native forests, making wood production sustainable (Ferreira et al., 2012).

Besides the studies on the asexual propagation of $T$. ciliata (Souza et al., 2009; Ferreira et al., 2012; Pereira et al., 2015), the production of seedlings in Brazil is based mainly on the commercialization of seeds. The species does not have standardization for the germination tests and therefore the seed quality analysis is can be compromised (Medeiros et al., 2015), bringing consequences for the producer. Based on this, the objective of this study was to determine basic information to subsidized standard conditions for the seed testing of T. ciliata, namely: temperature and photoperiod for the germination test and imbibition time and water volume for the electrical conductivity.

\section{Material and Methods}

The experiment was carried out at the laboratory of the Department of Horticulture and Forestry belonging to the Faculty of Agronomy of the Universidade Federal do Rio Grande do Sul (UFRGS). Although the seeds of T. ciliata were purchased from companies accredited in the Registro Nacional de Sementes e Mudas (RENASEM) and stored in a cold room at $5{ }^{\circ} \mathrm{C}$ until the experiments were installed. Each seed lot was characterized by the state of origin (Santa Catarina - SC, São Paulo - SP and Bahia - BA) and year of collection, being: SC 2014, SP 2014, SP 2015, BA 2014 and BA 2015.

\section{Moisture content}

The moisture content of the lots was determined by the oven method at $105 \pm 3{ }^{\circ} \mathrm{C}$ for $24 \mathrm{~h}$, according to the methodology described by Brasil (2009). Seeds were weighed on analytical balance before and after drying and the moisture content calculated on the basis of initial weight.

\section{Germination test}

Seeds were removed from storage, separated from impurities and disinfested in $70 \%$ alcohol for 30 seconds and $1 \% \mathrm{NaClO}$ for 60 seconds, followed by washing in sterilized water for 60 seconds. Afterwards, they were placed on filter paper for superficial drying. Disinfestation was preestablished in a previous study.

They were then distributed in plastic boxes, previously washed with $70 \%$ alcohol and $1 \% \mathrm{NaClO}$, using blotting paper as substrates (Medeiros et al., 2015) and deionized water. The boxes containing the seeds were packed in plastic bags to prevent loss of water and placed in germinating chambers with temperature and photoperiod regulation. The moisture of the blotter paper was monitored and $2 \mathrm{~mL}$ of sterilized water was added when necessary.

The number of germinated seeds was recorded daily for further calculation of the germination rate index (GR) (Maguire, 1962). Based on preliminary studies (data not published), the first germination count was evaluated (FC) after 10 days of incubation counting only the normal seedlings. The germination test ended after 21 days of incubation, recording the number of normal and abnormal seedlings, hard and dead seeds. For the classification of hard or dead, 
the seeds were pinched and if interior contents were expel out they were classified as dead, otherwise hard if they remained rigid. Normal seedlings were defined as those possessing the essential structures that are indicative of their ability to produce normal plants under favorable conditions (Elias et al., 2012).

\section{Photoperiod and temperature for germination test}

Germination tests were carried out at temperatures of 15 , 20,25 and $30^{\circ} \mathrm{C}$ and in photoperiods of 0,12 and $16 \mathrm{~h}$ of light generate by white $20 \mathrm{~W}$ fluorescent lamps. For $0 \mathrm{~h}$ of light, the plastic boxes were wrapped in aluminum foil in order to avoid any light coming in, and the evaluation of the daily germination and the first germination count were omitted.

In this experiment only the seeds of the BA 2015 lot were used, regarding the higher percentage of germination (unpublished data).

\section{Imbibition curve}

The seeds of the BA 2015 lot were removed from storage and weighed in an analytical balance of four decimal places. Afterwards, germination tests were carried out at temperatures of $15,20,25$ and $30^{\circ} \mathrm{C}$, under a photoperiod of $12 \mathrm{~h}$ of light. Soon after incubation, the seeds were weighed at two-hour intervals till complete $12 \mathrm{~h}$ of incubation. After that, the weighing was performed at 12-hour intervals, shutting down until $156 \mathrm{~h}$ of incubation, or when more than $50 \%$ of the seeds had already emitted the radicle. At each weighing, the seeds were removed from the plastic box, dried superficially with filter paper, weighed and put back into the plastic box. For each temperature, four replications containing 25 seeds each were used.

For each weighing interval, the weight gain calculation was performed according to the equation (Albuquerque et al., 2009):

$$
W G(\%)=\left(\frac{F W-I W}{I W}\right) \times 100
$$

In which: $\mathrm{WG}=$ weight gain; $\mathrm{FW}=$ final weight of each interval; IW = initial weight prior to imbibition.

\section{Electrical conductivity}

The seeds were first weighed into analytical balance, and then inserted into beaker cups containing either $50 \mathrm{~mL}$ or 100 $\mathrm{mL}$ of deionized water. The cups were sealed with Parafilm $\mathrm{M}{ }^{\circledR}$ in order to avoid evaporation of the water and placed in the germinating chamber regulated at $25^{\circ} \mathrm{C}$.

The electrical conductivity of the solution was measured with a Digimed DM-32 conductivity meter after 6, 12, 24, 36, $48,60,72,84,96$ and $108 \mathrm{~h}$ of seed imbibition.

\section{Correlation between tests}

With the germination test and electrical conductivity data, the Pearson correlation was applied between the variables: number of normal seedlings in the temperature and photoperiod recommended for the germination test, and electrical conductivity of the solution in the time and volume in which there was greater distinction two lots.

\section{Statistical procedures}

For the photoperiod and temperature for germination test, the treatments were arranged in a factorial scheme $3 \times$ 4 (photoperiod $\times$ temperature), each replication consisting of a plastic box containing 50 seeds. Data were submitted to analysis of variance and polynomial regression. The best fit models were choose based on comparison models using analysis of variance.

For electrical conductivity, all seed lots were used and the treatments were arranged in factorial scheme $2 \times 5 \times 10$ (water volume $\times \operatorname{lot} \times$ imbibition seed time). The data were submitted to analysis of variance, with each replication composed of a beaker containing 25 seeds. Within each imbibition time and volume of water, the electrical conductivity averages were compared by the Tukey test at 5\%.

The design was completely randomized in all experiments, each treatment being composed of four replications. Data were submitted to the Shapiro-Wilk normality test and the Bartlett variance homogeneity test. All analyzes and graphs were performed using RStudio software (version 1.0.136).

\section{Results and Discussion}

The SP 2014, BA 2014 and BA 2015 lots presented an initial moisture content lower than $10 \%$ (Table 1 ), which is adequate to maintain viability during the storage of orthodox seed (Bonner, 2008; Karrfalt, 2008). On the other hand, the SC 2014 and SP 2015 lots contained an average of $13.09 \%$ of moisture content.

Table 1. Initial moisture content of Toona ciliata var. australis seed lots marketed in Brazil.

\begin{tabular}{cc}
\hline Lots & Moisture content (\%) \\
\hline SC 2014 & $12.9 \mathrm{a}$ \\
SP 2014 & $6.9 \mathrm{c}$ \\
SP 2015 & $13.2 \mathrm{a}$ \\
BA 2014 & $9.8 \mathrm{~b}$ \\
BA 2015 & $9.9 \mathrm{~b}$ \\
\hline
\end{tabular}

In which: SC 2014 = Santa Catarina lot collected in 2014; SP 2014 = São Paulo lot collected in 2014; SP 2015 = São Paulo lot collected in 2015; BA 2014 = Bahia lot collected in 2014; BA 2015 = Bahia lot collected in 2015. Means followed by the same letters in the column do not differ statistically by the Tukey test at $5 \%$. 


\section{Photoperiod and temperature for germination test}

The GR variable showed a quadratic behavior with maximum value at $28^{\circ} \mathrm{C}$, where the germination occurred in less time (Figure 1 - A). Similar results were observed for the FC variable, but only for the seeds submitted to the $16 \mathrm{~h}$ of light (Figure 1 - B). Using $12 \mathrm{~h}$ of light the response was linear, showing $47.55 \%$ of germinated seeds at $30{ }^{\circ} \mathrm{C}$.
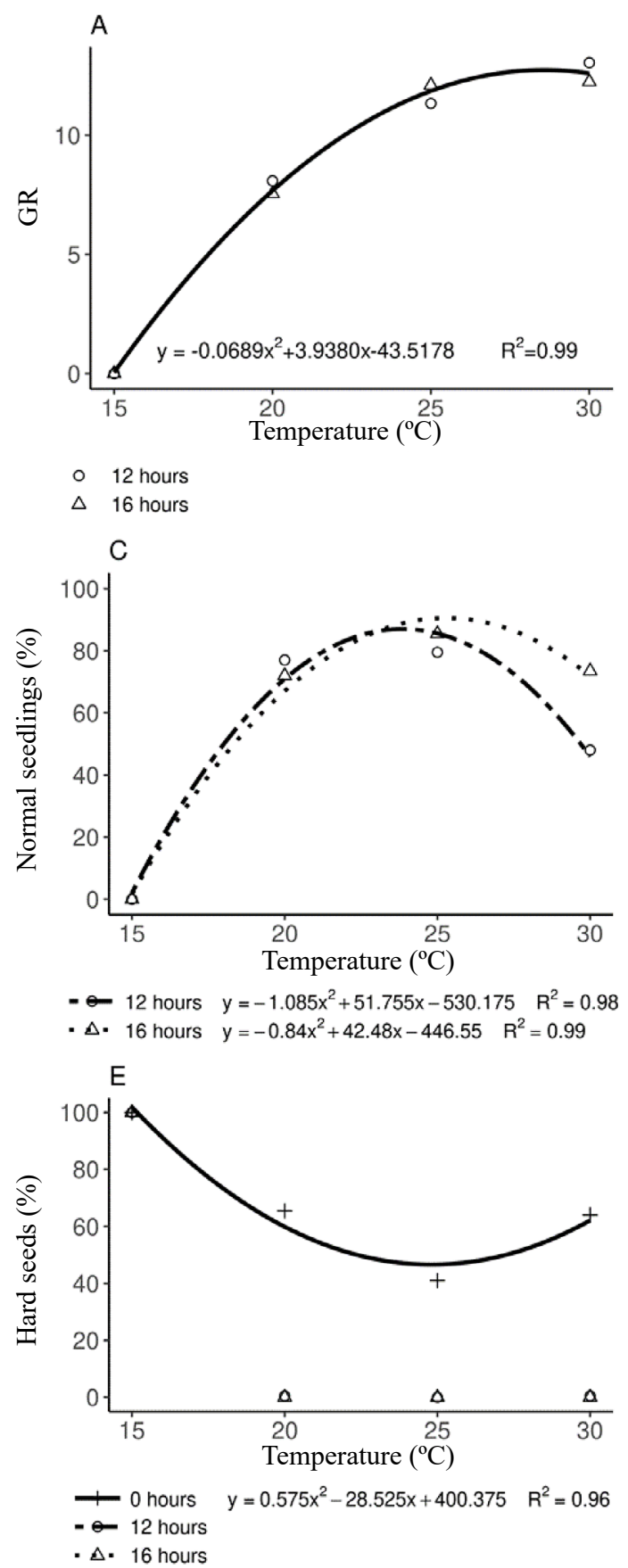

These results corroborate with those of other works related to the germination of tropical forest species, like Tecoma stans L. Juss. ex Kunth (Socolowski et al., 2008), Caesalpinia ferrea Mart. Ex Tul. (Melo et al., 2017), Euterpe precatoria Mart. (Costa et al., 2018), and several others Brazilian native species (Brancalion et al., 2010).

T. ciliata showed rapid germination at temperatures of
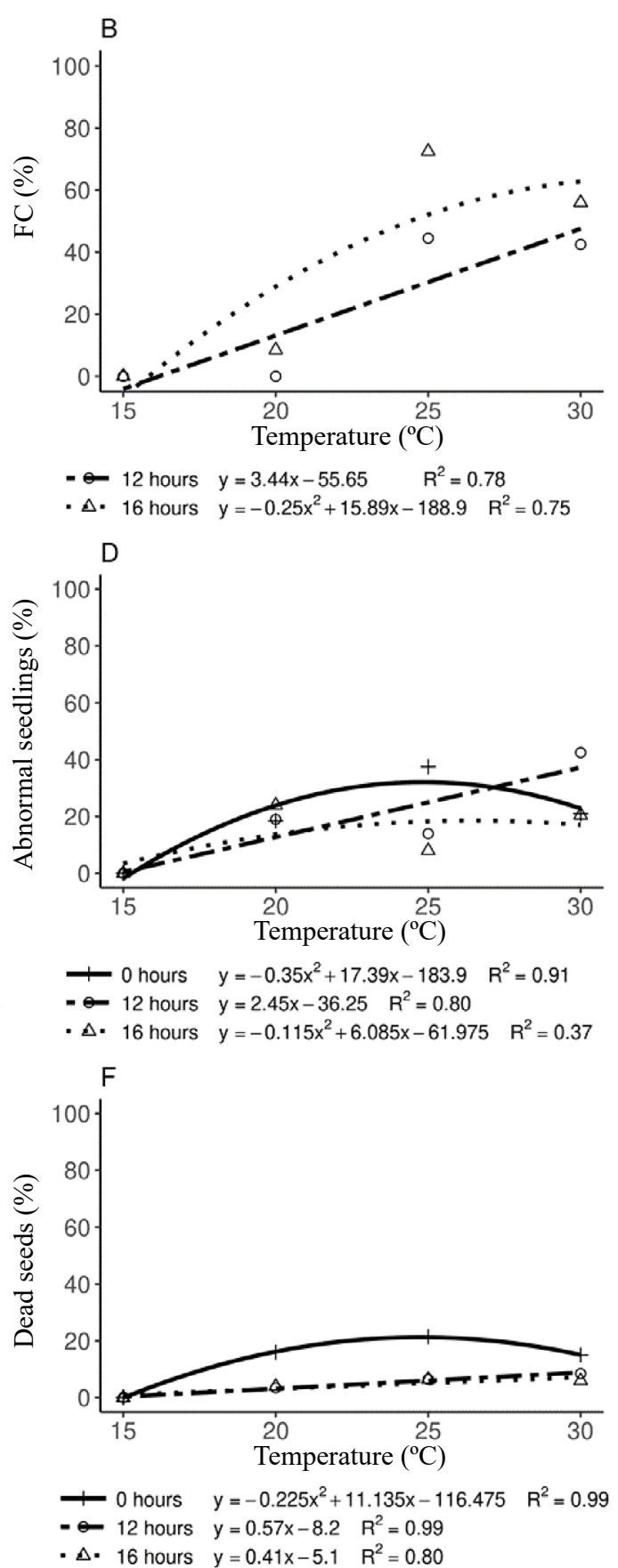

Figure 1. Germination test of Toona ciliata var. australis seeds under different photoperiod and temperatures. A-GR (germination rate); B - FC (first count); C - Normal seedlings; D - Abnormal seedlings; E - Hard seeds; F - Dead seeds. 
$25^{\circ} \mathrm{C}$ with $16 \mathrm{~h}$ of light, in which more than $50 \%$ of their seeds had already germinated after 10 days of incubation (FC). Among the timber species of Australia, the germination of $T$. ciliata is classified as moderately rapid (Smith et al., 2008), corroborating with the data found in the present work.

Regarding normal seedlings, the data analysis showed a negative quadratic behavior for 12 and $16 \mathrm{~h}$ of light (Figure 1 - C). At $25{ }^{\circ} \mathrm{C}$ and $16 \mathrm{~h}$ of light the seeds generate $90.52 \%$ of normal seedlings, higher than that found for the $12 \mathrm{~h}$ of light, $87.01 \%$ at $24{ }^{\circ} \mathrm{C}$. At $12 \mathrm{~h}$ the seedlings did not handle the temperature effects and showed signs of wilt. This was not observed with $16 \mathrm{~h}$ of light, which could have helped the seeds overcome the deleterious effects caused by the high temperature. With $0 \mathrm{~h}$ of light all seedlings etiolated and were classified as abnormal seedlings. It was also observed that temperature of $30{ }^{\circ} \mathrm{C}$ generate a greater percentage of abnormal seedlings in the $12 \mathrm{~h}$ of light, a $20 \%$ increase compared to $16 \mathrm{~h}$ (Figure $1-\mathrm{D}$ ). The higher temperature tolerance with $16 \mathrm{~h}$ of light may have occurred due to the enhanced activity of leaf aquaporins. According to Maurel et al. (2008), the enhanced activity of leaf aquaporins may favor water transport into the inner leaf tissues when transpiration is maximal, avoiding damage to the plant. In the total absence of light, the maximum value for abnormal seedlings was similar to that found for normal seedlings, which was at $25^{\circ} \mathrm{C}$.

The value of normal seedlings generated at $25{ }^{\circ} \mathrm{C}$ and $16 \mathrm{~h}$ of light was higher to that found in other works with $T$. ciliata (Smith et al., 2008; Medeiros et al., 2015; Migliorini et al., 2015), demonstrating, therefore, that these conditions are ideal for germination tests with this species, since they provide low interferences in the viability of the seeds. Regardless of light hours, all seeds submitted to a temperature of $15^{\circ} \mathrm{C}$ did not germinate but remained hard until the final evaluation. The increase in temperature reduced the amount of hard seeds, being null in the 12 and $16 \mathrm{~h}$ of light with temperature between 20 and $30^{\circ} \mathrm{C}$. In the absence of light, there was also a reduction of hard seeds, with a negative quadratic behavior in which the minimum value at $25{ }^{\circ} \mathrm{C}$ was $46.60 \%$, higher than seeds at 12 and $16 \mathrm{~h}(0 \%)$.

This work showed the effect of the photoperiod and temperature interaction on seed germination $(p<0,001)$, since the data demonstrate that the temperature increase provided stimuli for germination, but it was not enough for the seeds submitted to absence of light. Low germination in the absence of light was also observed in Acacia polyphylla DC. seeds, in which the use of only $1 \mathrm{~h}$ of daily light was sufficient to double the amount of germinated seeds (Araújo-Neto et al., 2003).

\section{Imbibition curve}

The first $12 \mathrm{~h}$ of incubation were characterized by a rapid imbibition of water, in which the weight gain in relation to the initial mass reached values above $100 \%$, regardless of temperature (Figure 2). Then, the seeds weight remained stable for a different period at each temperature $\left(96 \mathrm{~h}\right.$ at $20^{\circ} \mathrm{C}$ and $36 \mathrm{~h}$ at 25 and $30^{\circ} \mathrm{C}$ ). With the emission of the radicle, another increase in weight gain was observed, rising gradually as more seeds emitted the radicle. This experiment showed the three-phase pattern of the T. ciliata germination, in which Phase I is characterized by a rapid imbibition of water, Phase II by weight stabilization, and Phase III by increasing weight gain after stabilization.

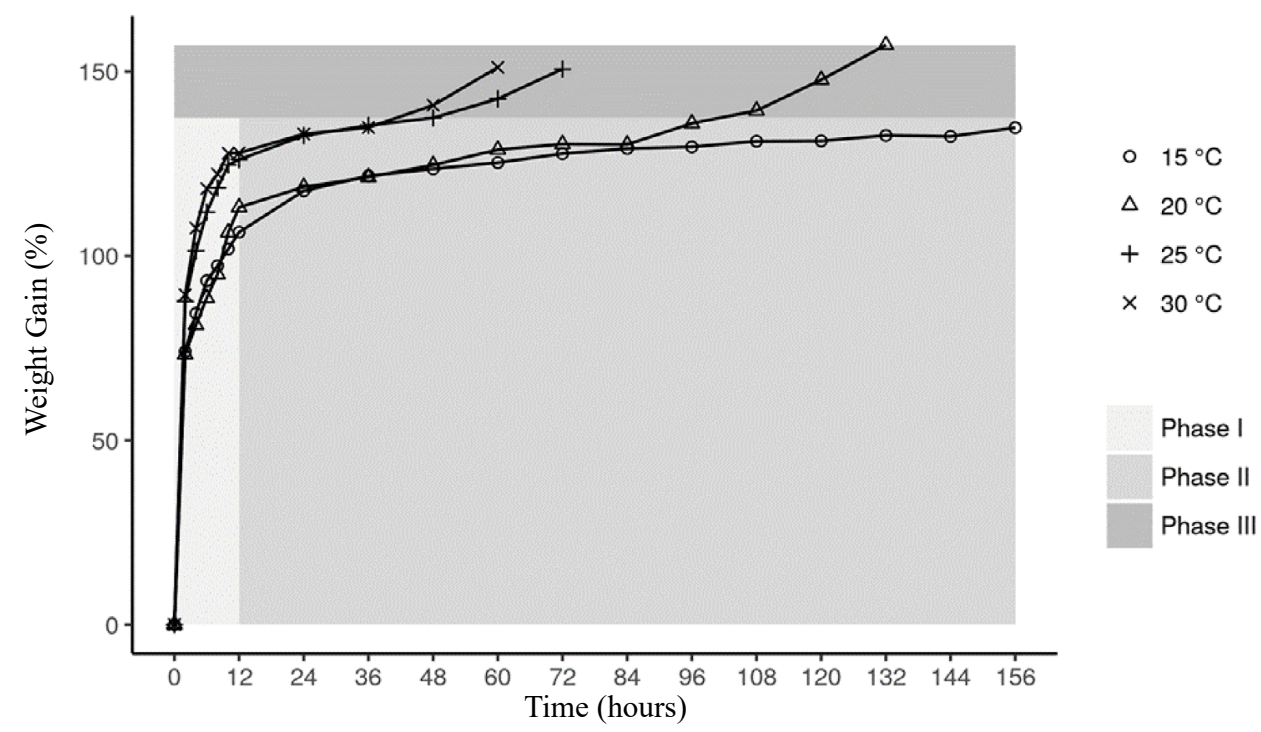

Figure 2. Imbibition curve of Toona ciliata var. australis seeds under $12 \mathrm{~h}$ of photoperiod and different temperatures. 
Phase I occurs in seeds with physiological dormancy, not dormant, viable or dead, as it is a consequence of the matrix forces of the osmotic gradient between seed and water, that is, it is an essentially physical process (Bewley et al., 2013). Some cases may hinder the absorption of water at this stage, such as the presence of hard integument in the seed forming a barrier to water entry (Dübbern-Souza and Marcos-Filho, 2001). The T. ciliata seeds do not possess this property, allowing a rapid imbibition soon after contact with water. At the end of Phase I the seeds submitted to temperatures of 15 and $20^{\circ} \mathrm{C}$ absorbed less water than at 25 and $30{ }^{\circ} \mathrm{C}$.

A greater prolongation of the Phase II was observed at $15^{\circ} \mathrm{C}$, corroborating with the data obtained in the germination test at the same temperature, resulting in $100 \%$ of hard seeds at the end of the test (21 days). Phase II is affected by the osmotic potential of the water sources for the seed and the environment temperature, having a longer duration with lower the temperature due to the low respiratory rate of the embryo (Bewley et al., 2013).

\section{Electrical conductivity}

The results showed differences between the lots at all times and volumes tested, but with different group formations between each time and volume (Table 2). Lot separation was more sensitive in 24-hour soak to the $50-\mathrm{mL}$ volume, and in 60 hour soak to $100 \mathrm{~mL}$, at which points the group by the means test was identical. To facilitate the execution of the test, it could be indicated the time of $24 \mathrm{~h}$ and $50 \mathrm{~mL}$ of volume of water to perform the electrical conductivity test for $T$. ciliata. The BA 2015 lot presented the lowest electrical conductivity among the lots tested, indicating a greater vigor in relation to the others.
When water is soaked, cell membranes reorganize and repair the damage from storage, but until the repair is complete, several cell solutes are leached into the medium (Schmidt, 2007). The increase of the imbibition time allowed a greater quantity of solutes to be leached, a fact also observed for other forest species like Dalbergia nigra (Vell.) Fr. All. ex Benth. (Marques et al., 2002), Sebastiania commersoniana (Bail) Smith \& Downs (Santos and Paula, 2005) and Dictyoloma vendellianum A. Juss (Flavio and Paula, 2010).

The use of more seeds could reduce the amount of soaking required for lot separation, as demonstrated by Santos and Paula (2005), in which the use of $25 \%$ more seeds decreased in $16 \mathrm{~h}$ the time to separate lots of Sebastiania commersoniana (Bail) Smith \& Downs seeds. The electrical conductivity test was also efficient for the lots separation of Dalbergia nigra (Vell.) Fr.All. ex Benth., in which the use of 30 or $36 \mathrm{~h}$ for the imbibition of the seeds is recommended (Marques et al., 2002).

\section{Correlation between tests}

All tests showed a higher quality of the BA 2015 lot, which was classified as high viability and vigor. There was also a significant correlation between the amount of germination test normal seedlings at $25{ }^{\circ} \mathrm{C}$ and $16 \mathrm{~h}$ of light and the electrical conductivity after $24 \mathrm{~h}$ of imbibition in $50 \mathrm{~mL}\left(-0.8386^{* *}\right)$, showing that lots with low electrical conductivity can germinate more normal seedlings. The electrical conductivity test yields satisfactory results for the viability assessment and can be used as a complementary test to the germination test.

According to Elias et al. (2012) the electrical conductivity test is not effective for all crops, but the correlation between

Table 2. Electrical conductivity $\left(\mu \mathrm{S} \mathrm{cm}^{-1} \cdot \mathrm{mg}^{-1}\right)$ of Toona ciliata var. australis seed lots marketed in Brazil, with different volumes and imbibition period.

\begin{tabular}{|c|c|c|c|c|c|c|c|c|c|c|}
\hline \multirow{2}{*}{ Lots } & \multicolumn{10}{|c|}{$50 \mathrm{~mL}$} \\
\hline & $6 \mathrm{~h}$ & $12 \mathrm{~h}$ & $24 \mathrm{~h}$ & $36 \mathrm{~h}$ & $48 \mathrm{~h}$ & $60 \mathrm{~h}$ & $72 \mathrm{~h}$ & $84 \mathrm{~h}$ & $96 \mathrm{~h}$ & $108 \mathrm{~h}$ \\
\hline SC 2014 & $328.7 \mathrm{a}$ & $347.1 \mathrm{a}$ & $366.5 \mathrm{~b}$ & $429.7 \mathrm{a}$ & $477.5 \mathrm{ab}$ & $521.1 \mathrm{ab}$ & $569.4 \mathrm{ab}$ & $591.5 \mathrm{ab}$ & $619.9 \mathrm{ab}$ & $634.3 \mathrm{ab}$ \\
\hline SP 2014 & $343.9 \mathrm{a}$ & $364.4 \mathrm{a}$ & $440.5 \mathrm{a}$ & $498.5 \mathrm{a}$ & $526.1 \mathrm{a}$ & $582.9 \mathrm{a}$ & $654.7 \mathrm{a}$ & $695.5 \mathrm{a}$ & $740.1 \mathrm{a}$ & $748.6 \mathrm{a}$ \\
\hline SP 2015 & $296.5 \mathrm{ab}$ & $321.9 \mathrm{ab}$ & $373.6 \mathrm{~b}$ & $428.1 \mathrm{a}$ & $445.6 \mathrm{~b}$ & $471.7 \mathrm{~b}$ & $507.2 \mathrm{~b}$ & $529.2 \mathrm{~b}$ & $564.3 \mathrm{~b}$ & $576.2 \mathrm{~b}$ \\
\hline BA 2014 & $248.7 \mathrm{~b}$ & $260.9 \mathrm{~b}$ & $246.8 \mathrm{c}$ & $265.8 \mathrm{~b}$ & $265.3 \mathrm{c}$ & $278.8 \mathrm{c}$ & $290.2 \mathrm{c}$ & $295.1 \mathrm{c}$ & $299.0 \mathrm{c}$ & $306.8 \mathrm{c}$ \\
\hline BA 2015 & $166.3 \mathrm{c}$ & $179.3 \mathrm{c}$ & $170.5 \mathrm{~d}$ & $180.9 \mathrm{~b}$ & $181.7 \mathrm{~d}$ & $188.2 \mathrm{c}$ & $208.1 \mathrm{c}$ & $215.0 \mathrm{c}$ & $223.2 \mathrm{c}$ & $223.6 \mathrm{c}$ \\
\hline \multirow{2}{*}{ Lots } & \multicolumn{10}{|c|}{$100 \mathrm{~mL}$} \\
\hline & $6 \mathrm{~h}$ & $12 \mathrm{~h}$ & $24 \mathrm{~h}$ & $36 \mathrm{~h}$ & $48 \mathrm{~h}$ & $60 \mathrm{~h}$ & $72 \mathrm{~h}$ & $84 \mathrm{~h}$ & $96 \mathrm{~h}$ & $108 \mathrm{~h}$ \\
\hline SC 2014 & $175.8 \mathrm{ab}$ & $181.3 \mathrm{ab}$ & $202.0 \mathrm{~b}$ & $224.0 \mathrm{ab}$ & $224.0 \mathrm{ab}$ & $240.0 \mathrm{~b}$ & $257.5 \mathrm{ab}$ & $260.6 \mathrm{ab}$ & $278.1 \mathrm{ab}$ & $298.4 \mathrm{a}$ \\
\hline SP 2014 & $188.8 \mathrm{a}$ & $205.6 \mathrm{a}$ & $233.0 \mathrm{a}$ & $246.4 \mathrm{a}$ & $246.4 \mathrm{a}$ & $274.6 \mathrm{a}$ & $289.6 \mathrm{a}$ & $301.4 \mathrm{a}$ & $319.0 \mathrm{a}$ & $316.2 \mathrm{a}$ \\
\hline SP 2015 & $145.1 \mathrm{~b}$ & $161.2 \mathrm{~b}$ & $192.2 \mathrm{~b}$ & $200.9 \mathrm{~b}$ & $200.9 \mathrm{~b}$ & $220.6 \mathrm{~b}$ & $238.2 \mathrm{~b}$ & $244.8 \mathrm{bc}$ & $256.5 \mathrm{~b}$ & $261.3 \mathrm{ab}$ \\
\hline BA 2014 & $157.5 \mathrm{ab}$ & $169.7 \mathrm{~b}$ & $164.7 \mathrm{c}$ & $163.9 \mathrm{c}$ & $163.9 \mathrm{c}$ & $180.0 \mathrm{c}$ & $190.7 \mathrm{c}$ & $197.4 \mathrm{c}$ & $199.2 \mathrm{c}$ & $201.9 \mathrm{~b}$ \\
\hline BA 2015 & $81.7 \mathrm{c}$ & $86.54 \mathrm{c}$ & $86.74 \mathrm{~d}$ & $89.06 \mathrm{~d}$ & $89.06 \mathrm{~d}$ & $96.94 \mathrm{~d}$ & $103.1 \mathrm{~d}$ & $106.1 \mathrm{~d}$ & $115.0 \mathrm{~d}$ & $119.0 \mathrm{c}$ \\
\hline
\end{tabular}

In which: SC 2014 = Santa Catarina lot collected in 2014; SP 2014 = São Paulo lot collected in 2014; SP 2015 = São Paulo lot collected in 2015; BA 2014 = Bahia lot collected in 2014; BA 2015 = Bahia lot collected in 2015. Means followed by the same letters in the column do not differ statistically by the Tukey test at $5 \%$; ${ }^{\text {ns }}=$ not significant. 
these test and the germination test was also observed in other forest species, as in Jacaranda micrantha Cham. (Souza et al., 2016), Dalbergia nigra (Vell.) Fr.All. ex Benth. (Marques et al., 2002) and Corymbia citriodora (Hook.) K.D.Hill \& L.A.S. Johnson (Gonzale et al., 2011). Therefore, the use of these tests has shown to be promising in the evaluation of vigor in forest seeds, reducing the time necessary to classify lots according to the physiological quality.

\section{Conclusions}

For germination tests of Toona ciliata var. australis it is recommended to incubate the seeds in $16 \mathrm{~h}$ of light with temperature of $25^{\circ} \mathrm{C}$.

The electrical conductivity test should be performed with a volume of $50 \mathrm{~mL}$ and evaluated after $24 \mathrm{~h}$ of imbibition.

\section{References}

ALBUQUERQUE, K.S.; GUIMARÃES, R.M.; ALMEIDA, I.F.; CLEMENTE, A.C.S. Alterações fisiológicas e bioquímicas durante a embebição de sementes de sucupira-preta (Bowdichia virgilioides Kunth.). Revista Brasileira de Sementes, v.31, n.1, p.249-258, 2009. http://www.scielo.br/scielo.php?pid=S0101$31222009000100028 \&$ script $=$ sci abstract\&tlng $=$ pt

ARAÚJO-NETO, J.C.; AGUIAR, I.B.; FERREIRA, V.M. Efeito da temperatura e da luz na germinação de sementes de Acacia polyphylla DC. Brazilian Journal of Botany, v.26, n.2, p.249-256, 2003. http://www.scielo.br/scielo.php?script=sci_ arttext\&pid=S0100-84042003000200013

BASKIN, C.C.; BASKIN, J.M. Seeds: ecology, biogeography, and evolution of dormancy and germination.2nd. ed. San Diego: Elsevier/AP, 2014. 1586p.

BEWLEY, J.D.; BRADFORD, K.; HILHORST, H.; NONOGAKI, H. Seeds: physiology of development, germination and dormancy. 3rd. ed. New York: Springer New York, 2013. 392p.

BONNER, F.T. The woody plant seed manual. Washington: Government Printing Office, 2008. 1223p.

BRANCALION, P.H.S.; NOVEMBRE, A.D.D.L.C.; RODRIGUES, R.R. Temperatura ótima de germinação de sementes de espécies arbóreas brasileiras. Revista Brasileira de Sementes, v.32, n.4, p.15-21, 2010. http://www.scielo.br/scielo.php?pid=S0101$31222010000400002 \&$ script $=$ sci_abstract\&tlng $=$ pt

BRASIL. Ministério da Agricultura, Pecuária e Abastecimento. Regras para Análise de Sementes. Ministério da Agricultura, Pecuária e Abastecimento. Secretaria de Defesa Agropecuária. Brasília: MAPA/ACS, 2009. 395p.

BYGRAVE, F.L.; BYGRAVE, P.L. Growing australian red cedar and other meliaceae species in plantation. Canberra: Rural Industries Research and Development Corporation, 2005. 68p.
COSTA, C.R.X.; PIVETTA, K.F.L.; SOUZA, G.R.B.; MAZZINIGUEDES, R.B.; PEREIRA, S.T.S.; NOGUEIRA, M.R. Effects of temperature, light and seed moisture content on germination of Euterpe precatoria palm. American Journal of Plant Sciences, v.9, n.1, p.98-106, 2018. https://doi.org/10.4236/ajps.2018.91009

DÜBBERN-SOUZA, F.H.; MARCOS-FILHO, J. The seed coat as a modulator of seed-environment relationships in Fabaceae. Brazilian Journal of Botany, v.24, n.4, p.365-375, 2001. http:/www.scielo.br/ scielo.php?script $=$ sci_arttext\&pid $=$ S0100-84042001000400002

ELIAS, S.G.; COPELAND, L.O; MCDONALD, M.B.; BAALBAKI, R.Z. Seed testing: principles and practices. East Lansing: Michigan State University Press, 2012. 354p.

EL-KEBLAWY, A.; AL-RAWAI, A. Effects of seed maturation time and dry storage on light and temperature requirements during germination in invasive Prosopis juliflora. Flora - Morphology, Distribution. Functional Ecology of Plants, v.201, n.2, p.135-143, 2006. https://doi.org/10.1016/j.flora.2005.04.009

FENNER, M.; THOMPSON, K. The ecology of seeds. New York: Cambrige University Press, 2005. 262p.

FERREIRA, D.A.; BARROSO, D.G.; SILVA, M.P.S.; SOUZA, J.S.; FREITAS, T.A.S.; CARNEIRO, J.G.A. Influência da posição das miniestacas na qualidade de mudas de cedro australiano e no seu desempenho inicial no pós-plantio. Ciência Florestal, v.22, n.4, p.715-723, 2012. http://www.scielo.br/scielo.php?pid=S1980$50982012000400715 \&$ script $=$ sci abstract\&tlng=pt

FLAVIO, J.J.P.; PAULA, R.C. Testes de envelhecimento acelerado e de condutividade elétrica em sementes de Dictyoloma vendellianum A. Juss. Scientia Forestalis, v.38, n.87, p.391-399, 2010. http://hdl. handle.net/11449/71862

GODOI, S.; TAKAKI, M. Effects of light and temperature on seed germination in Cecropia hololeuca Miq. (Cecropiaceae). Brazilian Archives of Biology and Technology, v.47, n.2, p.185-191, 2004. http://www.scielo.br/scielo.php?script=sci arttext\&pid=S1516-89132004000200004

GONZALE，J.L.S.; VALERI， S.V.; PAULA， R.C. Qualidade fisiológica de sementes de diferentes árvores matrizes de Corymbia citriodora (Hook.) K.D.Hill \& L.A.S. Johnson. Scientia Forestalis, v.39, n.90, p.171-181, 2011. http://hdl.handle.net/11449/72480

KARRFALT, R.P. Seed testing. In: The woody plant seed manual. Washington: Forest Service, 2008. 1223p.

LUNA, B.; PÉREZ, B.; TORRES, I.; MORENO, J.M. Effects of incubation temperature on seed germination of mediterranean plants with different geographical distribution ranges. Folia Geobotanica, v.47, n.1, p.17-27, 2011. https://doi.org/10.1007/s12224-011-9110-0

MAGUIRE, J.D. Speed of germination-aid in selection and evaluation for seedling emergence and vigor. Crop Science, v.2, n.1, p.176-177, 1962.

MARAGHNI, M.; GORAI, M.; NEFFATI, M. Seed germination at different temperatures and water stress levels, and seedling emergence from different depths of Ziziphus lotus. South African Journal of Botany, v.76, n.3, p.453-459, 2010. https://doi. org/10.1016/j.sajb.2010.02.092 
MARQUES, M.A.; PAULA, R.C.; RODRIGUES, T.J.D. Adequação do teste de condutividade elétrica para determinar a qualidade fisiológica de sementes de jacarandá-da-bahia (Dalbergia nigra (Vell.) Fr. All. ex Benth.). Revista Brasileira de Sementes, v.24, n.1, p.271-278, 2002. http://www.scielo.br/scielo.php?script=sci_ arttext\&pid=S0101-31222002000100038

MAUREL, C.; VERDOUCQ, L.; LUU, D.T.; SANTONI, V. Plant aquaporins: membrane channels with multiple integrated functions. Annual Review of Plant Biology, v.59, p.595-624, 2008. https://doi. org/10.1146/annurev.arplant.59.032607.092734

MEDEIROS, L.R.; MONTEIRO, M.A.; MIGLIORINI, P.; LAZAROTTO, M.; TUNES, L.M. Standardization of germination test and response to $\mathrm{NaCl}$ salt stress in Toona ciliata seeds. Floresta, v.45, n.4, p.845-852, 2015. http://dx.doi.org/10.5380/rf.v45i4.39140

MELO, L.D.F.A.; MELO JUNIOR, J.L.A.; MAGALHÃES, I.D.; MEDEIROS, A.S.; MAIA JÚNIOR, S.O.; CORDEIRO JUNIOR, J.J.F.; SILVA, A.C. Temperature and substrate effects on the germination of Caesalpinia ferrea Mart. Ex Tul. African Journal of Agricultural Research, v.12, n.47, p.3348-3354, 2017. https://doi. org/10.5897/AJAR2017.12748

MIGLIORINI, P.; MEDEIROS, L.; MONTEIRO, M.A.; CARATTI, F.C.; LAZAROTTO, M.; TUNES, L.M. Efeito de diferentes substratos no desenvolvimento inicial de cedro australiano. Revista de Ciências Agroveterinárias, v.14, n.2, p.139-145, 2015. http:// revistas.udesc.br/index.php/agroveterinaria/article/view/5858

OLIVEIRA, A.K.M.; CARVALHO, J.M.B.; SOUZA, J.S.; SOUZA, S.A. Germination of Aspidosperma subincanum Mart. ex A. DC seeds at different temperatures. Revista Brasileira de Plantas Medicinais, v.17, n.4, p.642-648, 2015. http://www.scielo.br/scielo. php?script=sci_arttext\&pid=S1516-05722015000400642

PEREIRA, M.O.; WENDLING, I.; NOGUEIRA, A.C.; KALIL FILHO, A.N.; NAVROSKI, M.C. Resgate vegetativo e propagação de cedro-australiano por estaquia. Pesquisa Agropecuária Brasileira, v.50, n.4, p.282-289, 2015. http://seer.sct.embrapa.br/index.php/pab/ article/view/20557

SANTOS, S.R.G.; PAULA, R.C. Teste de condutividade elétrica para avaliação da qualidade fisiológica de sementes Sebastiania commersoniana (Bail) Smith \& Downs - Euphorbiaceae. Revista Brasileira de Sementes, v.27, n.2, p.136-145, 2005. http://www. scielo.br/scielo.php?pid=S0101-31222005000200020\&script $=$ sci abstract\&tlng $=\mathrm{pt}$
SCHMIDT, L. Tropical forest seed. Berlin: Springer-Verlag, 2007. 409p.

SMITH, N.J.C.; ZAHID, D.M.; ASHWATH, N.; MIDMORE, D.J. Seed ecology and successional status of 27 tropical rainforest cabinet timber species from Queensland. Forest Ecology and Management, v.256, n.5, p.1031-1038, 2008. https://doi.org/10.1016/j. foreco.2008.06.005

SOCOLOWSKI, F.; TAKAKI, M. Germination of Jacaranda mimosifolia (D. Don - Bignoniaceae) seeds: effects of light, temperature and water stress. Brazilian Archives of Biology and Technology, v.47, n.5, p.785-792, 2004. http://www.scielo.br/scielo. php?script $=$ sci_arttext\&pid=S1516-89132004000500014

SOCOLOWSKI, F.; VIEIRA, D.C.M.; TAKAKI, M. Interaction of temperature and light on seed germination in Tecoma stans L. Juss. ex Kunth (Bignoniaceae). Brazilian Archives of Biology and Technology, v.51, n.4, p.523-530, 2008. http://www.scielo.br/scielo. php?script $=$ sci_arttext\&pid=S1516-89132008000400010

SOUZA, J.C.A.V.; BARROS, D.G.; CARNEIRO, J.G.A.; TEIXEIRA, S.L.; BALBINOT, E. Propagação vegetativa de cedroaustraliano (Toona ciliata M. Roemer) por miniestaquia. Revista Árvore, v.33, n.2, p.205-213, 2009. http://www.scielo.br/scielo. php?pid=S0100-67622009000200002\&script $=$ sci_abstract\&tlng=pt

SOUZA, G.F.; GARLET, J.; DELAZERI, P. Teste de condutividade elétrica em sementes de Jacaranda micranta. Pesquisa Florestal Brasileira, v.36, n.85, p.79-83, 2016. https://doi.org/10.4336/2016. pfb.36.85.894

TILKI, F.; DIRIK, H. Seed germination of three provenances of Pinus brutia (Ten.) as influenced by stratification, temperature and water stress. Journal of Environmental Biology, v.28, n.1, p.133-136, 2007. https://www.ncbi.nlm.nih.gov/pubmed/17718000

VILELA, E.S.; STEHLING, E.C. Recomendações de plantio para cedro australiano. Campo Belo: Bela Vista Florestal, 2015. 20p.

YANG, Q.H.; WEI, X.; ZENG, X.L.; YE, W.H.; YIN, X.J.; MING, W.Z.; JIANG, Y.S. Seed biology and germination ecophysiology of Camellia nitidissima. Forest Ecology and Management, v.255, n.1, p.113-118, 2008. https://doi.org/10.1016/j.foreco.2007.08.028 